Queens, workers, and males alike are caught by the chaffinch, which usually, with a peck from its beak, first destroys the tail, dropping the latter to the ground, eats out the contents of the abdomen, then breaks into the thorax, and finally drops the hollow remains of the insect to the ground.

In 1912 young birds of a late brood accompanied their parents to two trees in Hertfordshire, but showed fear of the bees, and would eat them only when caught and offered by their parents.

The blue tit is said to treat hive-bees in much the same manner (Cheshire, "Bees and Bee-keeping," vol. ii., pp. $578-79$, I886).

The shrike; or "butcher-bird," pierces queen humble-bees through the side of the thorax, after catching them on the wing in its beak, apparently with the view of causing general paralysis before impalation upon the thorn during formation of the "larder."

Toads are known to feed voraciously upon hive-bees, swallowing them whole, and it is at present very doubtful if any of the birds mentioned are affected by the stings of bees; but the method of avoidance of being stung cannot be completely overlooked in the cases described for birds.

The cuckoo is especialiy addicted to feeding upon caterpillars provided with irritant hairs, and with this we have a rough series showing the downfall of distasteful qualities or defensive weapons in face of selective adaptation in enemies, which for generations must have been kept at bay by such protection in their would-be victims.

The currant-moth larva, then, has merely been eaten by the thrush, and possibly by the other birds mentioned by Dr. Collinge (save for the cuckoo, which is now adapted to eating distastful insects), when the stress of having to feed a family has made such a practice a necessity. In the case of the song-thrush and its young, the stress has disappeared after a period of seven days with the arrival on the scene of more palatable food.

The presence of parasites in the caterpillars left after this period can scarcely be more than a coincidence, and there is no proof that the caterpillars which the thrushes ate were not also parasitised. This explanation would seem more acceptable than Dr. Collinge's paradox based on the assumption that the larvæ of the currant moth are not unpalatable to the majority of birds in ordinarv times.

New College, Oxford, July 29

EDWARD R. Speyer.

\section{Luminous Worms.}

THE paper by Dr. Gilchrist published in the Transactions of the Royal Society of South Africa, and referred to in NATURE of July $3 \mathrm{I}, \mathrm{p} .433$, should be of service in reviving interest in this country in the question: Do our indigenous Oligochæts display luminosity? So long ago as I893 I directed attention to the subject in these columns (NATURE, vol. xlvii., p. 462), and in more recent years I have endeavoured to elicit information of a trustworthy nature on the question with but little success. The following worms which have been reported as exhibiting luminosity are common in this country:-Brandling (Allolobophora (Eisenia) foetida), Enchytraeus albidus, and Henlea nasuta. Microscolex phosphoreus or an ally is an importation Another worm, which is large, common, and easily observed, is Octolasium. It has a steelblue body, clay-coloured girdle, and yellow tail filled with fat cells which are often attended by gregarines. Various questions await solution. Of what service, for instance, can luminosity be to creatures which NO. 2597 , VOL. IO3] have no eyes? Helodrilus oculatus is the only Lumbricid found in England possessing organs of vision, and these are rudimentary. They have been reported by Eisen as occurring in Sparganophilus also, two species of which, as I recently showed, occur in this country. Is it possible that light can influence Annelids in some way, and so facilitate sexual processes? It was affirmed by Flaugergues in $177 \mathrm{I}$ that luminosity disappears in certain cases after copulation, and if that observation is trustworthy it is most suggestive. Dr. Gilchrist, in his paper on luminosity referred to above, suggests that luminosity is a protective device so far as South African worms are concerned, and his argument is very plausible. I believe that the yellow extremities of Octolasium serve the purpose of dazzling underground foes by emitting light.

The reports made years ago to the British Association of luminous worms found in Liverpool and in the bogs of Ireland have never led to any satisfactory issue. As I am now writing my monograph of British Oligochæts for the Ray Society, it would greatly interest and help me to receive living specimens of worms which betray phosphorescent properties, or any well-authenticated facts relating to the subject which could be used for purposes of publication or investigation.

"Cathay," Solihull, July 2 r.

Hilderic Friend.

\section{Protective Coloration of Birds and Eggs.}

WHILE collecting information on the use of colourprotection among birds, my attention has been directed to what appears to be a very interesting generalisation, viz. that among birds which nest on the moors, seashores, and similar open places, (I) those which have the habit of remaining on their nests when danger threatens generally wear camouflaged uniforms, but their eggs seldom show any signs of colour-protection; while (2) those which are very shy and leave their eggs readily are generally conspicuously coloured, but their eggs are usually camouflaged.

Amongst the first class are capercailzie, nightjar, partridge, wild duck, and bittern; and amongst the shy ones with camouflaged eggs are lapwing, curlew, oyster-catcher, terns, ringed plover, and golden plover.

I do not remember to have seen this point mentioned explicitly in any book or paper, and should be greatly obliged to any reader of NATURE interested in birds who would give me any further information on the subject.

The Museum, Keighley.

\section{Teeth of Sea-Otter.}

IT is commonly stated that the sea-otter (Latax lutris) differs from other carnivora in having only two incisor teeth in the lower jaw. Through the kindness of an old Etonian, Mr. Ernest Edwards, our school museum has become possessed of a fine stuffed head of this animal. I was surprised, however, to note that this specimen has three incisors on both sides. In the books of reference to which I have access I can find no such case recorded, and I shall be grateful if any of your readers can give me information on the point.

Eton College, Windsor, July 29. M. D. HILl.

\section{The Late Sir Edward Stirling.}

In Nature of April 3, p. 87, the late Sir Edward Stirling is referred to as director of the South Australian Museum. Sir Edward resigned from the direc. torate in I9I3, and was succeeded by Mr. Edgar R. 